\title{
Development and survival after transfer of cow embryos cultured from 1-2-cells to morulae or blastocysts in rabbit oviducts or in a simple medium with bovine oviduct epithelial cells
}

\author{
J. E. Ellington, P. B. Farrell, M. E. Simkin, R. H. Foote, E. E. Goldman and \\ A. B. McGrath*
}

Department of Animal Science, Cornell University, Ithaca, New York 14853-4801, USA; and

*EmTran, Inc., Elizabethtown, PA 17022, USA

\begin{abstract}
Summary. This study compares development of bovine 1-2-cell embryos in bovine oviduct epithelial cell co-culture (Group EC) with a glucose- and serum-free simple medium (CZB), or after surgical transfer to ligated oviducts of rabbits (Group RO). Embryos were surgically collected from superovulated donor cows $40-48 \mathrm{~h}$ after the beginning of oestrus and randomly distributed between the two groups. Embryos were cultured or incubated for 5 days. In Exp. 1, embryo quality scores and total numbers of cells in the two groups were compared. In Exp. 2, pairs of similarly treated morulae were transferred to each of 10 or 12 recipients in the Groups $\mathrm{RO}$ and $\mathrm{EC}$, respectively. Total cell counts per embryo in both groups averaged $52(P>0.05)$, and the in-vitro culture system was equivalent to the rabbit oviducts in promoting embryo development for all characteristics measured. Embryo survival, as determined by ultrasound between Days 39 and 43 after oestrus, in 13 ideal recipients was $57 \%$ for embryos in Group EC and 58\% for embryos Group RO. None of the 9 less desirable recipients was pregnant for either group. These results establish that cattle zygotes can develop to morulae in culture with bovine oviduct epithelial cells in a simple medium and can produce normal pregnancy rates.
\end{abstract}

Keywords: cattle; zygote; co-culture; embryo transfer; pregnancy

\section{Introduction}

The developmental block of bovine embryos cultured in vitro at the 8-16-cell stage is well documented and an impediment to the study of early embryo development and the application of many modern biotechniques (Wright \& Bondoli, 1981; Eyestone \& First, 1986; Heyman et al., 1987; Bavister, 1988). Since the first report of early embryonic development of sheep embryos in rabbit oviducts (uterine tubes) in 1955 (Averill et al., 1955), the use of intermediate hosts for culture of zygotes fertilized in vitro or in vivo has been widespread (Boland, 1984; Sirard et al., 1985; Lu et al., 1987; Wall \& Hawk, 1988). However, the drawbacks of using a living intermediate host are numerous, including embryo loss, technical support requirements, animal costs, care and welfare.

To avoid these problems, different methods of embryo and cell co-culture have been explored to overcome the 8-16-cell developmental block in cattle (Heyman et al., 1987; Lu et al., 1987; Eyestone \& First, 1989; Goto et al., 1989; Rexroad, 1989). Numerous cell types have been used, including trophoblastic vesicles, fibroblasts, luteal cells, granulosa cells, endometrial cells and oviduct epithelial cells. With sheep embryos, no difference in developmental rate was seen between embryos co-cultured in oviduct epithelial cells or other cell types, but pregnancy rates after transfer 
were superior for embryos co-cultured with oviduct cells (Gandolfi \& Moor, 1987; Rexroad \& Powell, 1988). Even with these reported successes many embryologists continue to use intermediate rabbit or other host oviducts (Shioya et al., 1988; Hawk et al., 1989), due to inconsistent results with co-culture.

Ellington et al. (1989a) have shown the advantage of a more simple medium for co-culture of bovine zygotes and oviduct epithelial cells. This glucose- and serum-free medium (CZB) was developed by Chatot et al. (1989) to support mouse embryos through their developmental block in vitro. For early bovine embryos medium CZB alone did not support maturation beyond 8-16-cells (Ellington et al., 1989a), but co-culture with oviduct epithelial cells in Medium CZB gave better support to embryo development than did more complex serum-containing media.

This paper describes an experiment designed to evaluate development of 1-2-cell cow embryos fertilized in vivo and then incubated in rabbit oviducts or co-cultured with oviduct epithelial cells in Medium CZB for 5 days. Embryonic development was assessed subjectively by scoring morphology, by staining and counting cells and by embryo survival following embryo transfer.

\section{Materials and Methods}

Experimental design. The study consisted of embryos distributed randomly from each of 13 donors into two treatments for culture in rabbit oviducts (Group RO) or monolayers of bovine oviduct epithelial cells (Group EC). More embryos were placed in rabbit oviducts to compensate for possible losses during recovery. Five donors provided embryos for Exp. 1 in which embryonic development in the two treatments was quantitatively compared. A random one-third of the embryos obtained from the 8 donors in Exp. 2 were used for quantitative comparison of embryo development, while the remaining embryos were used for non-surgical embryo transfer.

Statistical significance in both experiments was tested by Student's $t$ test for comparisons of total cell counts, pycnotic nuclei, a mitotic index, and embryo quality grade. Categorical data, such as percentage blastulation and percentage of pregnant recipients, were analysed by $\chi^{2}$ tests.

Oviduct cell monolayer preparation. Oviducts from slaughter-house cattle in the follicular phase of the oestrous cycle were cannulated and $10 \mathrm{ml}$ phosphate-buffered saline (PBS: Gibco, Grand Island, NY, USA) plus $1 \%$ polyvinyl alcohol and $2 \%$ of commercially available antibiotic/antimycotic (Gibco) were flushed through the oviduct and collected in a conical centrifuge tube. Detached oviduct cells obtained in the medium flushed from 2 cows were pooled and washed twice in PBS. A $0.25 \mathrm{ml}$ pellet of clumps of epithelial cells was then resuspended in $5 \mathrm{ml} \mathrm{Ham}$ 's F $10+$ $10 \%$ fetal bovine serum (FBS) $+5 \mu \mathrm{g}$ insulin $/ \mathrm{ml}, 5 \mu \mathrm{g}$ transferrin $/ \mathrm{ml}, 5 \mathrm{ng}$ selenium $/ \mathrm{ml}$ (ITS) and $10 \mu \mathrm{g}$ epidermal growth factor/ml (EGF) (Collaborative Research, Lexington, MA, USA), and 2\% antibiotic/antimycotic (Gibco). This system was found previously to support good growth of oviduct epithelial cells (Ellington et al., 1989a). The cell suspension was pipetted in $0.5 \mathrm{ml}$ portions into 4-well tissue-culture plates, and cultured at $39^{\circ} \mathrm{C}$ in $5 \% \mathrm{CO}_{2}$ and air. After 24-36 h most unattached cells were removed with a medium change. Monolayers used in this study formed within 4-6 days and were utilized for embryo culture within 1-2 weeks.

Collection of 1-2 cell bovine embryos. Holstein virgin and first calf heifers were superovulated using the supplier's recommended dose of $20 \mathrm{mg}$ follicle-stimulating hormone (FSH: Folltropin: Vetrepharm, London, Ontario, Canada, $35 \mathrm{mg}$ NIH-FSH-S-1 standard) beginning on Days 8-12 of their oestrous cycle. The FSH was given every $12 \mathrm{~h}$ for 4 days and $750 \mu \mathrm{g}$ cloprostenol (Estrumate: Bayvet, Shawnee, KS, USA) was given with the seventh FSH injection. Cattle displayed oestrus $36-48 \mathrm{~h}$ after prostaglandin administration and were inseminated with frozen semen every $12 \mathrm{~h}$ after the start of observed standing oestrus until $24 \mathrm{~h}$ after the end of oestrus, with a range of $2-4$ inseminations. Surgical collection of embryos was done $40-48 \mathrm{~h}$ after the start of standing oestrus. Animals were anaesthetized using thiamylal sodium and maintained on halothane inhalant. A midline ventral incision was used to exteriorize and flush both oviducts. Details of these procedures have been described by Ellington et al. (1989b).

Collected flush medium was transported to the laboratory where embryos and ova were located and washed three times in fresh PBS. Embryo developmental stage was recorded and all embryos and ova were transferred to designated treatments within $1 \mathrm{~h}$ of collection. In order to decrease light exposure and handling time no effort was made to try to identify unfertilized ova from zygotes at the time of treatment assignment.

Transfer to rabbit oviducts. A random one-half to two-thirds of the embryos from each donor were loaded into a flexible transfer pipette with a minimal amount of PBS $(\leqslant 15 \mu \mathrm{l})$. The transfer pipette was made by transecting a tomcat catheter in half. The narrow catheterization end of the cut catheter was adapted to a tuberculin syringe which provided aspiration to load and deposit the embryos.

The rabbits had been treated with $1.2 \mu \mathrm{g}$ of a GnRH analogue (Receptal: Hoechst-Roussel, Somerville, NJ, USA) $24 \mathrm{~h}$ before transfer to induce pseudopregnancy, and were anaesthetized with $30 \mathrm{mg}$ xylazine (Rompun: Butler, Columbus, OH, USA) and $150 \mathrm{mg}$ ketamine (Ketaset: Aveco, Fort Dodge, IA, USA). After a midline ventral surgical approach, a ligature was placed at the utero-tubal junction and the transfer pipettecontaining 6 embryos: $\mathrm{JW}_{\mathrm{as}} 1 \mathrm{AM}$ 
placed $2 \mathrm{~cm}$ inside the oviduct ampulla and the embryos deposited. After 5 days the rabbits were killed and the oviducts were flushed with $3 \mathrm{ml}$ PBS for embryo recovery. Recovered embryos were evaluated for quality and developmental stage (see below).

Co-culture of embryos. At the time of embryo recovery Ham's F10 was removed from the wells containing the oviduct epithelial cells. All wells were then rinsed twice with Medium CZB to remove residual glucose and serum and covered with $0.5 \mathrm{ml} \mathrm{CZB}$ medium for co-culture. The random portion of embryos used for the culture treatment were co-cultured in glucose-free medium CZB for $36-48 \mathrm{~h}$, by which time embryos had developed to 8 cells. The medium was then changed to CZB plus 3.3mM-glucose and ITS/EGF (as described above) to maintain the cell monolayer and associated embryos. Embryos were cultured for 5 days at $39^{\circ} \mathrm{C}$ in $5 \% \mathrm{CO}_{2}$ and air.

Embryo cell counts (Exp. 1). On the Sth day of incubation in rabbit oviducts or co-culture, embryo quality was graded as $1=$ excellent, 2 = good, $3=$ fair, $4=$ poor and $5=$ degenerate; stage of development, i.e. morula or blastocyst, was also recorded (Hasler et al., 1987). After grading, embryos were fixed in $1 \%$ formaldehyde, stained in Hoechst 33342 DNA stain for $3 \mathrm{~min}$, and then viewed with an epifluorescence microscope (Pursel et al., 1985). Total cell number as well as number of pycnotic nuclei and percentage of cells in mitosis for each embryo (mitotic index) were recorded.

Embryo transfer (Exp. 2). Virgin cyclic Holstein heifers (and 1 multiparous cow) were synchronized to the embryo donors by using cloprostenol. All animals were classified by commercial standards for embryo transfer as suitable or unsuitable recipients. Of the 22 recipients injected with prostaglandin for synchronization, 13 animals showed standing oestrus synchronized to within $36 \mathrm{~h}$ from a donor's oestrus and had a crowned, healthy corpus luteum (CL) and a normal reproductive tract, as evaluated by rectal palpation just before transfer. These animals were chosen as suitable recipients. The other 9 recipients were evaluated and considered to be unsuitable at the time of transfer, but as no other recipients were available they were also used rather than discarding valuable treated embryos. Four of these recipients were not seen in standing oestrus, 4 had a poorly formed corpus luteum and 1 had excessive uterine tone and irregular oestrous activity at the time of embryo transfer.

Embryos from both treatments were graded as in Exp. 1. Primarily excellent and good embryos were transferred with the exception of 3 fair quality embryos from the rabbit oviduct group. Two morulae of comparable quality from the same donor and treatment were transferred together non-surgically to the recipient's uterus, ipsilateral to the CL. Transfers were done on Day 6 of the donor's oestrous cycle.

Recipients were examined with ultrasound and palpated per rectum 39-43 days after oestrus. Observation of the fetus by ultrasound was the end point of the experiment, as the high cost of maintenance precluded further boarding of animals at the experimental facility. Furthermore, calving rates for single pregnancies in the absence of disease have been reported to be only $4 \%$ lower than pregnancies detected at the time reported here (Leipold, 1978). However, increased pregnancy losses have been observed by several authors after the transfer of 2 embryos (Seike et al., 1989). All pregnant recipients were sold to local farmers and re-examined after 90 days of gestation by palpation.

\section{Results}

The 13 donor cows used in this experiment averaged $23 \pm 2.5$ (mean \pm s.e.) corpora haemorrhagica at the time of surgery with a mean of $17 \pm 1.6$ embryos and ova recovered. Recovery rate, as judged by number of embryos and ova versus number of corpora haemorrhagica, was $74 \%$. Of those recovered $11 \%$ were unfertilized, $79 \%$ were zygotes and $10 \%$ consisted of 2 -cells at the time of surgery, most of the latter coming from surgical collections closer to $48 \mathrm{~h}$ after the start of standing oestrus.

Of the 96 embryos and/or ova transferred to rabbit oviducts, $62(65 \%)$ were recovered. Between 3 and 16 embryos and ova from each donor were transferred to an individual rabbit oviduct and recovery rates varied from 0 to $100 \%$ for a given oviduct.

\section{Experiment 1: embryo cell counts}

There were no significant differences $(P>0.05)$ in total cell counts of embryos co-cultured with oviduct cells or incubated in rabbit oviducts (Table 1). The proportion of embryos developing past 16-cells was similar for both groups, as was the percentage of mitotic cells seen per embryo, and the percentage of morulae and blastocysts formed by Day 5 of culture $(P>0.05)$. Embryo grade score, based on visual observation, was also not different. However, there were more $(P<0.05)$ pycnotic nuclei in embryos that had been co-cultured. 
Table 1. Development of cattle embryos after fertilization in vivo and transfer for 5 days to the rabbit oviduct or to co-culture with bovine oviduct epithelial cells

\begin{tabular}{lcc}
\hline & $\begin{array}{c}\text { Incubation in } \\
\text { rabbit oviduct } \\
\text { (Group RO) }\end{array}$ & $\begin{array}{c}\text { Co-culture with } \\
\text { epithelial cells } \\
\text { (Group EC) }\end{array}$ \\
\hline $\begin{array}{l}\text { No. of embryos } \\
\text { Mean }( \pm \text { s.e.) cell count }\end{array}$ & 29 & 37 \\
Range of cell counts & $4-6$ & $52 \pm 7$ \\
$\begin{array}{l}\text { No. ( } \pm \text { s.e.) of pycnotic nuclei } \\
\text { per embryo }\end{array}$ & $2 \pm 0 \cdot 8^{\mathrm{a}}$ & $4-139$ \\
$\begin{array}{l}\text { Mitotic index* }( \pm \text { s.e.) } \\
\text { Embryo quality grade }( \pm \text { s.e.) }\end{array}$ & $0 \cdot 5 \pm 0 \cdot 13$ & $5.5 \pm 0 \cdot 7^{\mathrm{b}}$ \\
No. developing to morulae + & $2 \cdot 9 \pm 0 \cdot 18$ & $2 \cdot 8 \pm 0 \cdot 2$ \\
$\quad$ blastocysts & $24 / 29(83 \%)$ & $31 / 37(84 \%)$ \\
$\begin{array}{l}\text { No. developing to blastocysts } \\
\text { (\%) }\end{array}$ & $4 / 29(14 \%)$ & $5 / 37(14 \%)$ \\
\hline
\end{tabular}

${ }^{\text {ab }}$ Row means with different superscripts differ, $P<0.05$.

* Mean percentage of cells in mitosis per embryo.

\section{Experiment 2: embryo transfer}

Similar percentages $(P>0.05)$ of morulae in both groups were of excellent or good quality after the 5 days of treatment ( $44 \%$ in Group RO and $49 \%$ in Group EC). These were considered to be acceptable for transfer to recipients.

Embryo survival in the 13 first-choice heifers, judged in advance by experienced embryo transfer specialists to be suitable, were similar $(58 \%$ versus $57 \%$, Table 2$)$. Second-choice recipients were used to obtain maximum possible numbers of observations, only because embryos were available. However, none of these animals were pregnant in either group. After 90 days of gestation, 1 animal carrying twins in both treatment groups was no longer pregnant.

Table 2. Embryo survival and pregnancy rates after 39-43 days in recipient cows each receiving 2 embryos which had been incubated in a rabbit oviduct or co-cultured with oviduct epithelial cells

\begin{tabular}{|c|c|c|c|}
\hline & & $\begin{array}{l}\text { Incubation in } \\
\text { rabbit oviduct } \\
\text { (Group RO) }\end{array}$ & $\begin{array}{l}\text { Co-cultured with } \\
\text { epithelial cells } \\
\text { (Group EC) }\end{array}$ \\
\hline First choice suitable recipients & $\begin{array}{l}\text { Total no. of recipients } \\
\text { No. of recipients pregnant }(\%) \\
\text { No. of fetuses observed (as \% of } \\
\text { those transferred) }\end{array}$ & $\begin{array}{l}6 \\
4(66) \\
7(58)\end{array}$ & $\begin{array}{l}7 \\
4(57) \\
8(57)\end{array}$ \\
\hline $\begin{array}{l}\text { Second choice recipients, with } \\
\text { reproductive problems }\end{array}$ & $\begin{array}{l}\text { Total no. of recipients } \\
\text { No. of recipients pregnant }\end{array}$ & $\begin{array}{l}4 \\
0\end{array}$ & $\begin{array}{l}5 \\
0\end{array}$ \\
\hline Overall embryo survival (\%) & & 35 & 33 \\
\hline
\end{tabular}

\section{Discussion}

This is believed to be the first report for cattle of successful co-culture of 1- to 2-cell cattle embryos to morulae and blastocysts in a simple serum-free medium and of a direct comparison of pregnancy rates following in-vitro embryo co-culture versus embryo incubation in an in-vivo host oviduct. These experiments show that early cattle embryos co-cultured in a simple semi-defined medium

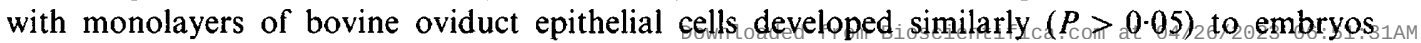


incubated in an intermediate host, the rabbit. Total cell counts for the embryos from both treatments were similar as were pregnancy rates. Pregnancy rates for the good quality recipients were similar to those obtained by commercial embryo transfer companies performing non-surgical transfers on Day 7 of the donor's cycle (Hasler et al., 1987).

Camous et al. (1984) cultured 1 -cell cow embryos in a medium with $15 \%$ fetal calf serum and obtained $18 \%$ morulae. With trophoblastic vesicle co-culture $42 \%$ developed into morulae. Ten transferred blastocysts that had been frozen after in-vitro and in-vivo culture, resulted in 4 pregnancies. One pregnancy extended beyond 45 days and resulted in a normal calf. Eyestone \& First (1989) obtained similar pregnancy rates $(55 \%)$ to those reported here after transfer of in-vitro fertilized cow embryos co-cultured with oviduct cells in TCM199 and serum to the morula or blastocyst stage.

Although previous studies have failed to show a significant difference in pregnancy rates between recipients with a good $\mathrm{CL}(>1.5 \mathrm{~cm}$, and crowned) versus those with poorer quality $\mathrm{CL}$ $(<1.5 \mathrm{~cm}$, no crown; Hasler et al., 1987; Remsen \& Roussel, 1982), none of the recipients in this experiment with a poor CL or with other reproductive anomalies maintained a pregnancy with treated embryos. This may be due to the small number of animals involved, but, in part, it is possible that a compromised maternal environment plus any stresses on embryos from the 5 days of incubation caused a failure of maternal recognition and maintenance of pregnancy.

Recovery rate of embryos from the rabbit on Day $5(65 \%)$ was similar to the $50-77 \%$ rate reported by others (Boland, 1984; Sirard et al., 1985; Wall \& Hawk, 1988; Fukui \& Ono, 1988). The loss of embryos in an intermediate host is a serious and costly drawback to this method of embryo development. Losses could perhaps be reduced by inserting embryos further into the oviducts, but this is difficult in the rabbit due to the tortuous nature of the oviduct (Boland, 1984). In contrast, embryo co-culture allows for daily appraisal of the embryo (if desired) and losses are limited to culture contamination or equipment failure, which are rare with experienced personnel.

Although there were more $(P<0.05)$ pycnotic nuclei in co-cultured embryos than in those from rabbit oviducts, the overall proportion remained low and did not appear to affect development, as judged by quality score, total cell count, blastulation or pregnancy establishment. The percentage of embryos that formed blastocysts was equal in both groups and similar to that found in non-surgical embryo recoveries on Day 6 (Lindner \& Wright, 1983; Betteridge, 1977). The percentage of cells in visible mitosis at the time of staining was similarly low for both treatments. Because embryo division was not arrested before fixing, this represents the cells with DNA visibly condensed at the time of fixation. The value of this characteristic is presently unknown, but was recorded for further comparison of the two treatments.

Use of a simple medium containing pyruvate, lactate and glutamine, with no glucose, has proved to be superior for early embryonic development in several species, including mice and hamsters, and with co-culture in cattle (Chatot et al., 1989; Ellington et al., 1989c; Seshagiri \& Bavister, 1989). In cattle, glycolysis may be blocked as late as the blastocyst stage and glutamine can be ultilized as an energy source (Rieger \& Guay, 1988). The role of glutamine in earlier stage bovine embryos has not been evaluated. The presence of $3.3 \mathrm{mM}$-glucose in Medium CZB for the first 36-48 h of co-culture of 1-2-cell cow embryos significantly $(P<0.05)$ decreased the percentage of embryonic blastulation (13\% versus $31 \%$ ) by Day 6.5 in culture when compared to Medium CZB without glucose in the initial culture period (Ellington et al., 1989c). In this study, glucose and growth factors (ITS/EGF) were added to the medium after the embryos had reached 8 cells to preserve the integrity of the cell monolayer for the duration of culture in a serum-free medium. Preliminary trials without this addition resulted in destruction of over $75 \%$ of the monolayer.

Oviduct epithelial cell co-culture of 1-2-cell cattle embryos offers a much less expensive method for early embryonic development past the 8-16-cell in-vitro block than does the use of intermediate, live host animals. In this study, embryo appearance, cell count and ability to establish pregnancy after incubation of embryos in rabbit oviducts or co-culture with bovine oviduct epithelial cells were equal. 
In conclusion, this report provides a successful method, using a semi-defined, simple serum-free medium with oviduct cell co-culture, to develop 1-2-cell cattle embryos into morulae and blastocysts. This medium did not contain glucose until embryos had developed beyond 8-cells. Embryo survival following non-surgical transfer resulted in normal pregnancy rates.

This work was done as part of the National Cooperative Program on Non-Human In Vitro Fertilization and Preimplantation Development and was funded in part by the National Institute of Child Health and Human Development, NIH, through Cooperative Agreement HD 21939. We thank Dr Carol Ziomek for introducing us to the CZB medium; Upjohn and Vetrepharm for supplying pharmaceuticals; Eastern Artificial Insemination Coop., Inc. for semen used in the study; R. Larson, B. Blinn, B. Wilcox, D. Bianchi, E. Vance, S. Baker and Dr A. Stock for technical assistance; Dr J. Hasler at Em Tran, Inc., for transfer assistance; and D. Bevins for manuscript preparation.

\section{References}

Averill, R.W., Adams, C.E. \& Rowson, L.E. (1955) Transfer of mammalian ova between species. Nature, Lond. 176, 167-169.

Bavister, B. (1988) Role of oviductal secretions in embryonic growth in vivo and in vitro. Theriogenology 29, 143-154.

Betteridge, K. J. (1977) Embryo transfer in farm animals. Monograph Canada Dept. of Agriculture, No. 16, pp. $1-9$.

Boland, M.P. (1984) Use of the rabbit oviduct as a screening tool for the viability of mammalian eggs. Theriogenology 21, 126-137.

Camous, S., Heyman, Y., Meizou, W. \& Menezo, Y. (1984) Cleavage beyond the block stage and survival after transfer of early bovine embryos cultured with trophoblastic vesicles. J. Reprod. Fert. 72, 479-485.

Chatot, C.L., Ziomek, C.A., Bavister, B.D., Lewis, G.L. \& Torres, I. (1989) An improved culture medium supports development of random-bred 1 -cell mouse embryos in vitro. J. Reprod. Fert. 86, 679-688.

Ellington, J.E., Carney, E.W., Simkin, M.E., Farrell, P.B. \& Foote, R.H. (1989a) Comparison of media in an early bovine embryo and oviduct epithelial cell co-culture system. Theriogenology 31, 189, abstr.

Ellington, J.E., Farrell, P.B., Simkin, M.E. \& Foote, R.H. (1989b) A reliable effective method for obtaining bovine zygotes produced in vivo. Am. J. vet. Res. (in press).

Ellington, J.E., Carney, E.W., Farrell, P.B., Simkin, M.E. \& Foote, R.H. (1989c) Bovine 1-2-cell embryo development using a semi-defined medium in three oviduct epithelial cell co-culture systems Biol. Reprod. (in press).

Eyestone, W.H. \& First, N.L. (1986) A study of the 8to 16-cell developmental block in bovine embryos cultured in vitro. Theriogenology 25, 152, abstr.

Eyestone, W.H. \& First, N.L. (1989) Co-culture of early cattle embryos to the blastocyst stage with oviducal tissue or in conditioned medium. J. Reprod. Fert. 85, $715-720$.

Fukui, Y. \& Ono, H. (1988) In vitro development to blastocyst of in vitro matured and fertilized bovine oocytes. Vet. Rec. 122, 282.

Gandolfi, F. \& Moor, R.M. (1987) Stimulation of early embryonic development in the sheep by co-culture with oviduct epithelial cells. J. Reprod. Fert. 81, 23-28.

Goto, K., Kajihara, Y., Koba, M., Kosaka, S., Nakanishi, Y. \& Ogawa, K. (1989) In vitro fertilization and development of in vitro matured bovine follicular oocytes. J. Anim. Sci. 67, 2181-2185.

Hasler, J.F., McCauley, A.D., Lathrop, W.F. \& Foote, R.H. (1987) Effect of donor-embryo-recipient interactions on pregnancy rate in a large-scale bovine embryo transfer program. Theriogenology 27, $139-168$.

Hawk, H.W., Wall, R.J. \& Conley, H.H. (1989) Survival of DNA-injected cow embryos temporarily cultured in rabbit oviducts. Theriogenology 32, 243-253.

Heyman, Y., Menezo, Y., Chesne, P., Camous, S. \& Gornier, V. (1987) In vitro cleavage of bovine and ovine early embryos: improved development using coculture with trophoblastic vesicles. Theriogenology 27, 59-68.

Leipold, H.W. (1978) Genetics and disease in cattle. Proc. Ilth Conv. Am. Ass. Bovine Practioners, Baltimore, pp. 18-31.

Lindner, G.M. \& Wright, R.W. (1983) Bovine embryo morphology and evaluation. Theriogenology 20, 407-416.

Lu, K.H., Gordon, I., Gallagher, M. \& McGovern, H. (1987) Pregnancy established in cattle by transfer of embryos derived from in vitro fertilization of oocytes matured in vitro. Vet. Rec. 121, 259-260.

Pursel, V.G., Wall, R.J., Rexroad, C.E., Hammer, R.E. \& Brinster, R.L. (1985) A rapid whole-mount staining procedure for nuclei of mammalian embryos. Theriogenology 24, 687-700.

Remsen, L.G. \& Roussel, J.D. (1982) Pregnancy rates relating to plasma progesterone levels in recipient heifers at day of transfer. Theriogenology 18, $365-372$.

Rexroad, C.E. (1989) Co-culture of domestic animal embryos. Theriogenology 31, 105-112.

Rexroad, C.E. \& Powell, A.M. (1988) Co-culture of ovine eggs with oviductal cells and trophoblastic vesicles. Theriogenology 29, 387-397.

Rieger, D. \& Guay, P. (1988) Measurement of the metabolism of energy substrates in individual bovine

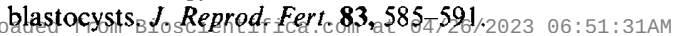


Seike, N., Saeki, K., Utaka, K., Sakai, M., Takakura, R., Nagao, Y. \& Kanagawa, H. (1989) Production of bovine identical twins via transfer of demi-embryos without zonae pellucida. Theriogenology 32, 211-220.

Seshagiri, P.B. \& Bavister, B.D. (1989) Glucose inhibits development of hamster 8-cell embryos in vitro. Biol. Reprod. 40, 599-606.

Shioya, Y., Kuwayama, M., Ueda, S., Saitou, S., Oota, H. \& Hanada, A. (1988) Effect of the time between slaughter and aspiration of follicles on the developmental capability of bovine oocytes matured and fertilized in vitro. Jap. J. Anim. Reprod. 34, 39-44.
Sirard, M.A., Lambert, R.D., Menard, D.P. \& Bedoya, M. (1985) Pregnancies after in-vitro fertilization of cow follicular oocytes, their incubation in rabbit oviduct and their transfer to the cow uterus. $J$. Reprod. Fert. 75, 551-556.

Wall, R.J. \& Hawk, H.W. (1988) Development of centrifuged cow zygotes cultured in rabbit oviducts. $J$. Reprod. Fert. 82, 673-680.

Wright, R.W., Jr \& Bondoli, K.R. (1981) Aspects of in vitro fertilization and embryo culture in domestic animals. J. Anim. Sci. 53, 702-729.

Received 18 September 1989 